\title{
Increased AURKA promotes cell proliferation and predicts poor prognosis in bladder cancer
}

Mengjie Guo ${ }^{1}$, Sicheng Lu', Hongming Huang ${ }^{2}$, Yaohui Wang ${ }^{3}$, Mary Q. Yang ${ }^{4}$, Ye Yang ${ }^{5,6}$, Zhimin Fan ${ }^{*}$, Bin Jiang ${ }^{5^{*}}$ and Youping Deng ${ }^{5,7^{*}}$

\begin{abstract}
Background: Bladder cancer $(\mathrm{BC})$ is the most common cancer of the urinary bladder and upper tract, in which the clinical management is limited. AURKA (aurora kinase A) has been identified as an oncogene in cancer development; however, its potential role and underlying mechanisms in the progression of BC remain unknown.

Results: In this study, we evaluated Aurora kinase A (AURKA) expression in patient samples by performing gene expression profiling, and found that AURKA expression levels were significantly higher in BC tissues than in normal tissues. Increased AURKA in BC was strongly associated with stage and grade. Moreover, BC patients with elevated AURKA achieved poor overall survival rates. The experiments in vitro comprehensively validated the critical role of AURKA in promoting BC cell proliferation using the methods of gene overexpression and gene silencing. Furthermore, we proved that AURKA inhibitor MLN8237 arrested BC cell growth and induced apoptosis.
\end{abstract}

Conclusions: These findings implicate AURKA acting as an effective biomarker for BC detection and prognosis, as well as therapeutic target.

Keywords: Bladder cancer, Aurora kinase a (AURKA), Oncogene, Apoptosis

\section{Background}

Bladder cancer $(\mathrm{BC})$ is the most prevalent malignant tumor of the urinary system, ranked as 9th commonest cause of cancer worldwide [1]. Irrespective of significant improvements in management, the recurrence and progression rates are still high, with a marked upward trend of morbidity and mortality annually [2]. Among the initial diagnosis, approximately $70 \%$ of patients are with non-muscle-invasive (non-MI) disease (stages Ta/T1/Tis), while others are muscle-invasive (MI) (stages T2-T4,[3]). Unfortunately, $20-30 \%$ of patients with non-MI tumors will eventually progress to a higher grade or stage such as MI disease during surveillance [4]. The prognosis for

\footnotetext{
*Correspondence: fanzm711@163.com; jbfirsth@aliyun.com; dengy@hawaii.edu

Ye Yang is the senior author of this manuscript.

Mengjie Guo, Sicheng Lu and Hongming Huang contributed equally to this work.

${ }^{5}$ National Medical Centre of Colorectal Disease, The Third Affiliated Hospital of Nanjing University of Chinese Medicine, Nanjing 210001, China Full list of author information is available at the end of the article
}

patients with advanced disease remains poor: 5-year survival rates are around $20 \%$ or lower for surgically incurable patients [5]. Clinicopathological factors such as stage and grade have been served as the substantial predictors of outcome, which are associated with enhanced possibilities of progression [6]. Many clinical trials have shown that BC is driven by genetic variations resulting in uncontrolled biologic behavior of the tumor [7]. Consequently, it is urgent to find novel molecular markers providing invaluable clues related to pathogenesis and prognosis in BC.

Aurora kinase A (AURKA) is a crucial member of the Aurora/Ipl1p kinase family, acting as a cell-cycle associated kinase on maintaining genomic integrity $[8,9]$. To ensure the successful completion of mitosis, AURKA is involved in separation and maturation of the central body, as well as stabilization at the spindle pole during chromosome segregation [10]. Aberrant activity of AURKA facilitates tumorigenic transformation and progression through defective control of the mitotic spindle checkpoint in mammalian cells and in several types of 
human tumors, including breast cancer [11], colorectal cancer [8], myeloid leukemia [12] and hepatocellular carcinoma [13]. The above points make AURKA as a tumor susceptibility locus $[14,15]$.

In this study, we performed sequential gene expression profiling (GEP) from patients of primary bladder cancer $(\mathrm{PBC})$ or undergoing radical cystectomy $(\mathrm{RC})$ to reveal the relationship between AURKA expression, clinical characteristics and overall survival. Finally, we aim to underlie the mechanism of AURKA in the progression of BC.

\section{Results}

\section{AURKA is overexpressed in BC tissues}

We explored the expression of AURKA in NC, Surrounding, PBC and RBC samples by performing GEP database analysis. AURKA expression was remarkably increased in $\mathrm{PBC}$ and $\mathrm{RBC}$ cells compared to $\mathrm{NC}$ and Surrounding $(P=0.000)$ (Fig. 1a). Furthermore, the outcome presented that AURKA expression was extremely higher in RBC samples than in PBC samples $(P=0.043)$.

\section{Increased AURKA is associated with clinicopathologic characteristics in BC patients}

The expression level of AURKA was extracted and correlated with available clinical parameters for the database of GSE13507 and GSE31684 (Table 1 and 2). In GSE13507, high expression of AURKA in PBC was dramatically associated with tumor stage $\left(\chi^{2}=11.815, P=0.019\right)$, grade $\left(\chi^{2}=\right.$ 17.927, $P=0.000)$, invasiveness $\left(X^{2}=13.229, P=0.001\right)$, and cancer-specific survival $\left(\chi^{2}=4.557, P=0.042\right)$. Similarly, high expression of AURKA in GSE31684 was closely linked to characteristics like stage $\left(X^{2}=18.766, P=0.001\right)$ and grade $\left(x^{2}=11.833, P=0.003\right)$. Nevertheless, no significant correlations between AURKA levels and gender, age, histology type, lymph node status and metastasis were observed in both datasets. The above results suggested that AURKA may play a role as potential diagnosed marker in $\mathrm{BC}$.
High AURKA levels are correlated to poor survival

As described in (Fig. 1b and c), kaplan-Meier survival curves showed a connection between high expression of AURKA in the primary tumors and reduced overall survival time of patients $(H R=1.98, P=0.012)$. Simultaneously, higher AURKA expression was linked to considerably shorter response duration of survival (HR $=1.84, P=0.047)$. It indicated that AURKA may act as a prognostic marker in $\mathrm{BC}$.

AURKA overexpression forces the proliferation of $B C$ cells To further verify that AURKA is a driver for BC cell proliferation, we overexpressed AURKA in two cell lines (T24 and J82). The elevated expression of AURKA in the overexpressing cells (OE) compared to the untransfected control cells (WT) was validated by Western blot (Fig. 2a). We evaluated the differences of growth rate between WT and OE cells in short-term cultures for three time points. The result showed that the cells exhibited a significantly increased rate of proliferation in $\mathrm{OE}$ cells relative to WT cells $(P=0.000)$ (Fig. $2 \mathrm{~b})$, which point out that AURKA is required for the promotion of $\mathrm{BC}$ cell growth in vitro.

\section{Silencing AURKA expression inhibits the proliferation of $B C$ cells}

siRNA technology was utilized to knockdown the endogenous expression of the AURKA gene in BC cells, which was confirmed by western blot as well. As shown in (Fig. 3a), AURKA expression was markedly reduced in BC cells transfected with AURKA siRNA (KD) compared to the control (WT). As shown in (Fig. 3b and c), the proliferation rate of T24 and J82 cells was drastically decreased followed by silencing AURKA at the three time points $(P=0.000)$. Subsequently, cleaved PARP and Caspase- 3 proteins were examined by western blotting to explore the functional mechanism of AURKA. Under the circumstance of siRNA
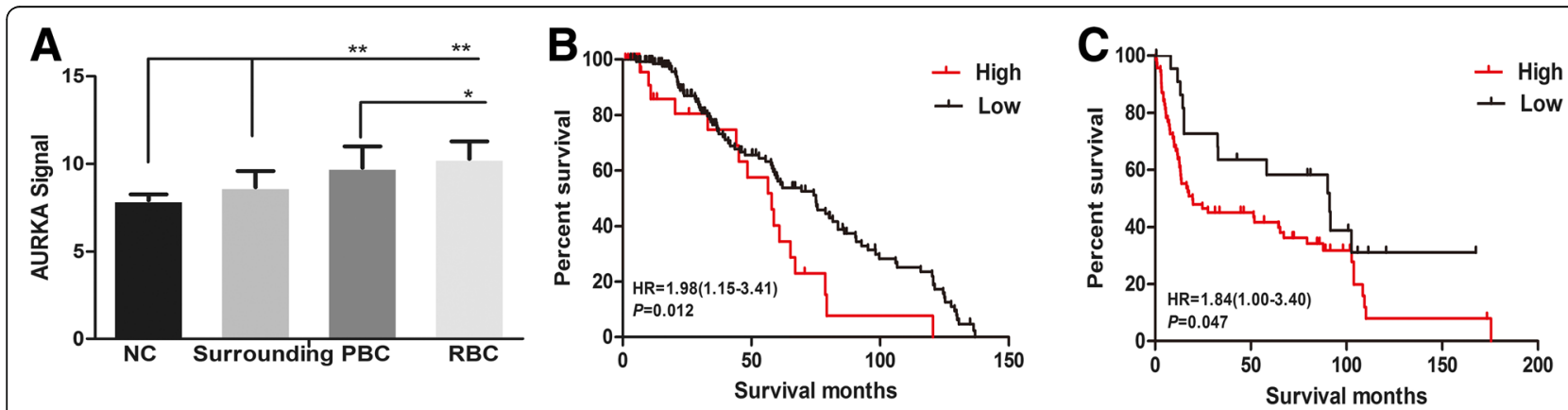

Fig. 1 AURKA levels are correlated with diagnosis and poor survival in bladder cancer patients. a AURKA expression of normal control cells (NC, $n=10$ ), normal looking bladder mucosae with surrounding carcinoma (Surrounding, $n=58$ ), primary bladder cancer (PBC, $n=165$ ) and recurrent bladder cancer (RBC, $n=23$ ) in GEP dataset. $\mathbf{b}$ and $\mathbf{c}$ Kaplan-Meier analysis on the overall survival of bladder cancer patients in b GSE13507 and c GSE31684 dataset based on the AURKA expression. $\left({ }^{*} P<0.05,{ }^{* *} P<0.01\right)$ 
Table 1 Correlation of AURKA expression and clinicopathologic characteristics of PBC in the datasheet of GSE 13507

\begin{tabular}{|c|c|c|c|c|c|}
\hline \multirow[t]{2}{*}{ Characteristic } & \multirow[t]{2}{*}{$n$} & \multicolumn{2}{|c|}{ AURKA expression (\%) } & \multirow[t]{2}{*}{ Pearson $x^{2}$} & \multirow[t]{2}{*}{$P$} \\
\hline & & High & Low or no & & \\
\hline Total & 165 & $30(18.18)$ & $135(81.82)$ & & \\
\hline Age & & & & 3.460 & 0.069 \\
\hline$\geq 65$ & 96 & $22(22.92)$ & $74(77.08)$ & & \\
\hline$<65$ & 69 & $8(11.59)$ & $61(88.41)$ & & \\
\hline Gender & & & & 1.774 & 0.196 \\
\hline Female & 30 & $8(26.67)$ & $22(73.33)$ & & \\
\hline Male & 135 & $22(16.30)$ & $113(83.70)$ & & \\
\hline Tumor stage & & & & 11.815 & $0.019^{*}$ \\
\hline $\mathrm{Ta}$ & 24 & $3(12.50)$ & $21(87.50)$ & & \\
\hline T1 & 80 & $8(10.00)$ & $72(90.00)$ & & \\
\hline $\mathrm{T} 2 \mathrm{a}+\mathrm{T} 2 \mathrm{~b}$ & 31 & $11(35.48)$ & $20(64.52)$ & & \\
\hline $\mathrm{T} 3 a+\mathrm{T} 3 \mathrm{~b}$ & 19 & $5(26.31)$ & $14(73.69)$ & & \\
\hline $\mathrm{T} 4 \mathrm{a}+\mathrm{T} 4 \mathrm{~b}$ & 11 & $3(27.27)$ & $8(72.73)$ & & \\
\hline Grade & & & & 17.927 & $0.000^{* *}$ \\
\hline low & 105 & $9(8.57)$ & $96(91.43)$ & & \\
\hline high & 60 & $21(35.00)$ & $39(65.00)$ & & \\
\hline Invasiveness & & & & 13.229 & $0.001^{* *}$ \\
\hline superical & 103 & $10(9.71)$ & $93(90.29)$ & & \\
\hline invasive & 62 & $20(32.26)$ & $42(67.74)$ & & \\
\hline Systemic chemo & & & & 0.002 & 1.000 \\
\hline Yes & 27 & $5(18.52)$ & $22(81.48)$ & & \\
\hline No & 138 & $25(18.11)$ & $113(81.89)$ & & \\
\hline Lymph node status & & & & 5.035 & 0.184 \\
\hline Nx & 1 & $0(0.00)$ & $1(100.00)$ & & \\
\hline No & 149 & $26(17.45)$ & $123(82.55)$ & & \\
\hline N1 & 8 & $2(25.00)$ & $6(75.00)$ & & \\
\hline N2 & 6 & $1(16.67)$ & $5(83.33)$ & & \\
\hline N3 & 1 & $1(100.00)$ & $0(0.00)$ & & \\
\hline Progression & & & & 1.492 & 0.299 \\
\hline No & 134 & $22(16.42)$ & $112(83.58)$ & & \\
\hline Yes & 31 & $8(25.81)$ & $23(74.19)$ & & \\
\hline Metastasis & & & & 0.075 & 1.000 \\
\hline No & 158 & $29(18.35)$ & $129(81.65)$ & & \\
\hline Yes & 7 & $1(14.28)$ & $6(85.72)$ & & \\
\hline Cancer-specific survival & & & & 4.557 & $0.042^{*}$ \\
\hline Survival & 133 & $20(15.04)$ & $113(84.96)$ & & \\
\hline Death & 32 & $10(31.25)$ & $22(68.75)$ & & \\
\hline
\end{tabular}

${ }^{*} P<0.05,{ }^{* * *} P<0.01$ significant difference between clinicopathologic characteristics of patients with high and low AURKA expression

interference, the protein levels of cleaved PARP and Caspase- 3 indicated the induction of apoptosis. Thus, the results further reinforce that AURKA displays an impressively positive effect on proliferation of $\mathrm{BC}$ cells in vitro.
Table 2 Correlation of AURKA expression and clinicopathologic characteristics in the datasheet of GSE31684

\begin{tabular}{|c|c|c|c|c|c|}
\hline \multirow[t]{2}{*}{ Characteristic } & \multirow[t]{2}{*}{$n$} & \multicolumn{2}{|c|}{ AURKA expression (\%) } & \multirow[t]{2}{*}{ Pearson $x^{2}$} & \multirow[t]{2}{*}{ P } \\
\hline & & High & Low or no & & \\
\hline Total & 93 & $70(75.27)$ & $23(24.73)$ & & \\
\hline Age & & & & 2.596 & 0.122 \\
\hline$\geq 65$ & 65 & $52(80.00)$ & $13(20.00)$ & & \\
\hline$<65$ & 28 & $18(64.29)$ & $10(35.71)$ & & \\
\hline
\end{tabular}

Gender

Female $\quad 25 \quad 19(76.00) \quad 6(24.00)$

Male $\quad 68 \quad 51(75.00) \quad 17(25.00)$

$\mathrm{RC}$ stage

$\begin{array}{llll}\text { pTa } & 5 & 0(0.00) & 5(100.00) \\ \text { pT1 } & 10 & 6(60.00) & 4(40.00) \\ \text { pT2 } & 17 & 13(76.47) & 4(23.53) \\ \text { pT3 } & 42 & 35(83.33) & 7(16.67) \\ \text { pT4 } & 19 & 16(84.21) & 3(15.79)\end{array}$

RC grade

high

low

Histology

$2.487 \quad 0.288$

$\begin{array}{llll}\text { TCC } & 86 & 63(73.25) & 23(26.75)\end{array}$

$\begin{array}{llll}\mathrm{TCC} / \mathrm{ClS} & 2 & 2(100.00) & 0(0.00)\end{array}$

TCC/square $\quad 5 \quad 5(100.00) \quad 0(0.00)$

Lymph node status

$5.876 \quad 0.053$

PNO

$49 \quad 32(65.31) \quad 17(34.69)$

$\mathrm{PN}+$

$28 \quad 25(89.28) \quad 3(10.72)$

PNX

$16 \quad 13(81.25) \quad 3(18.75)$

Recurrence

$\begin{array}{llll}\text { No } & 52 & 38(73.08) & 14(26.92)\end{array}$

Yes

$4132(78.05) \quad 9(21.95)$

Last known status

$\begin{array}{llll}\text { NED } & 28 & 18(64.28) & 10(35.72) \\ \text { DOC } & 27 & 22(81.48) & 5(18.52) \\ \text { DOD } & 38 & 30(78.95) & 8(21.05)\end{array}$

$2.651 \quad 0.266$

Metastasis

$\begin{array}{llll}\text { No } & 57 & 42(73.68) & 15(26.32)\end{array}$

$\begin{array}{llll}\text { Yes } & 36 \quad 28(77.78) & 8(22.22)\end{array}$

${ }^{* *} P<0.01$ significant difference between clinicopathologic characteristics of patients with high and low AURKA expression

\section{MLN8237 treatment suppresses BC cell proliferation}

We employed the AURKA selective inhibitor MLN8237 to evaluate its antitumor activity via targeting AURKA on the T24 and 882 cell lines. Treatment with $1 \mathrm{nM}$ and 2 nM MLN8237 respectively in T24 and J82 cells for $72 \mathrm{~h}$ exerted apparent inhibiton to $\mathrm{BC}$ cell growth $(P<0.01)$. The proliferation of T24 and J82 cells from initiation of 


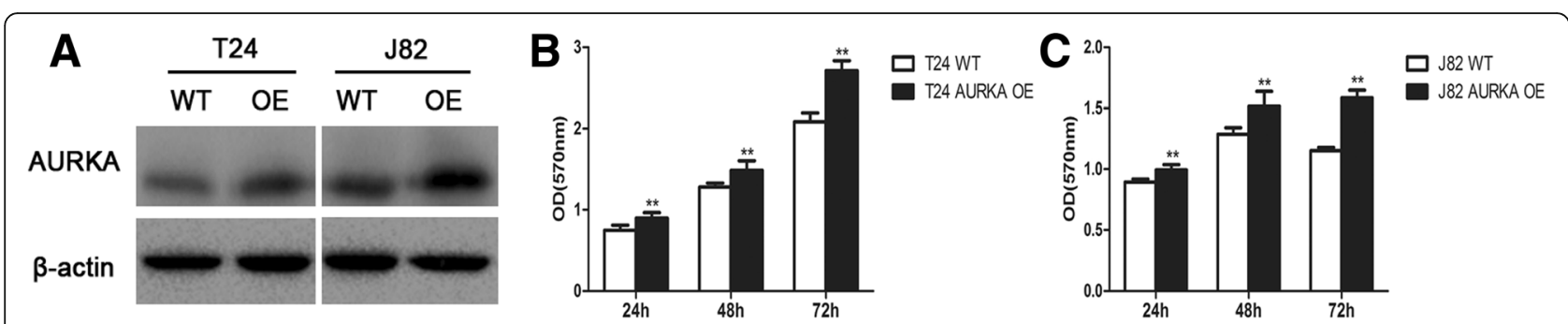

Fig. 2 AURKA overexpression forces the proliferation of BC cells. a AURKA expression in T24 and J82 cells were detected by western blot after AURKA-CDNA transfection. $\mathbf{b}$ and $\mathbf{c}$ Cell proliferation of $\mathbf{b}$ T24 and $\mathbf{c} J 82$ AURKA-overexpression (OE) and untransfected cells (WT). $\left({ }^{*} P<0.05\right.$, $\left.{ }^{* *} P<0.01\right)$

treatment to $24 \mathrm{~h}$ remained unaltered. The 48 -h treatment exhibited significant impact on inhibiting the proliferation of T24 cell $(P<0.01)$, as well as the growth of J82 cells was suppressed to a certain extent (Fig. $4 \mathrm{a}$ and b). Western blot analysis to test PARP and Caspase- 3 in T24 and J82 cells revealed that cleaved PARP and Caspase-3 proteins levels were highly increased (Fig. 4c). Taken together, the results underscored the potential of MLN8237 as an effective agent targeting AURKA in BC cells.

\section{Discussion}

Several observations have found that chromosomal anomalies, genetic polymorphisms, genetic and epigenetic alterations are involved in the tumorigenesis and progression of bladder cancer [16, 17]. Human chromosome 20 is of special interest due to its crucial role in the pathogenesis of diverse cancers [18, 19]. Gains and amplifications at chromosome 20q13.2 resulted in the induction and transformation of primary human urothelial cells, suggesting that overexpression of a gene or genes at this chromosomal locus is linked with the bladder tumor aggressiveness [20]. As a result, most of severe dysplasia or carcinoma manifests a high tendency to develop into high-grade papillary and nonpapillary tumors [15]. Thus, there is a dire need to investigate the specific oncogenes and gene amplification events at chromosome 20 , especially at the $20 \mathrm{q} 13$ region in BC.

Accumulating evidence with respect to the studies of oncogene has proved that AURKA, belonging to a family of mitotic kinases that maintain chromosomal stability, could promote tumor cell proliferation, diving tumorigenesis and tumor progression [21-23]. Amplification of AURKA has been observed in primary human urothelial cells at chromosome 20q13.2, which may play a key role in the development of $\mathrm{BC}$ [20]. In addition, overexpression of AURKA is interrelated with higher stages, grades and worse survival [24]. Zhou et al. showed that treating with AUKRA inhibitor increases the expression of apoptotic markers such as cleaved poly ADP-ribose polymerase (PARP) precipitating the suppression of BC cell proliferation [5]. Park et al. first investigated AURKA gene copy number in exfoliated cells of voided urine samples, and
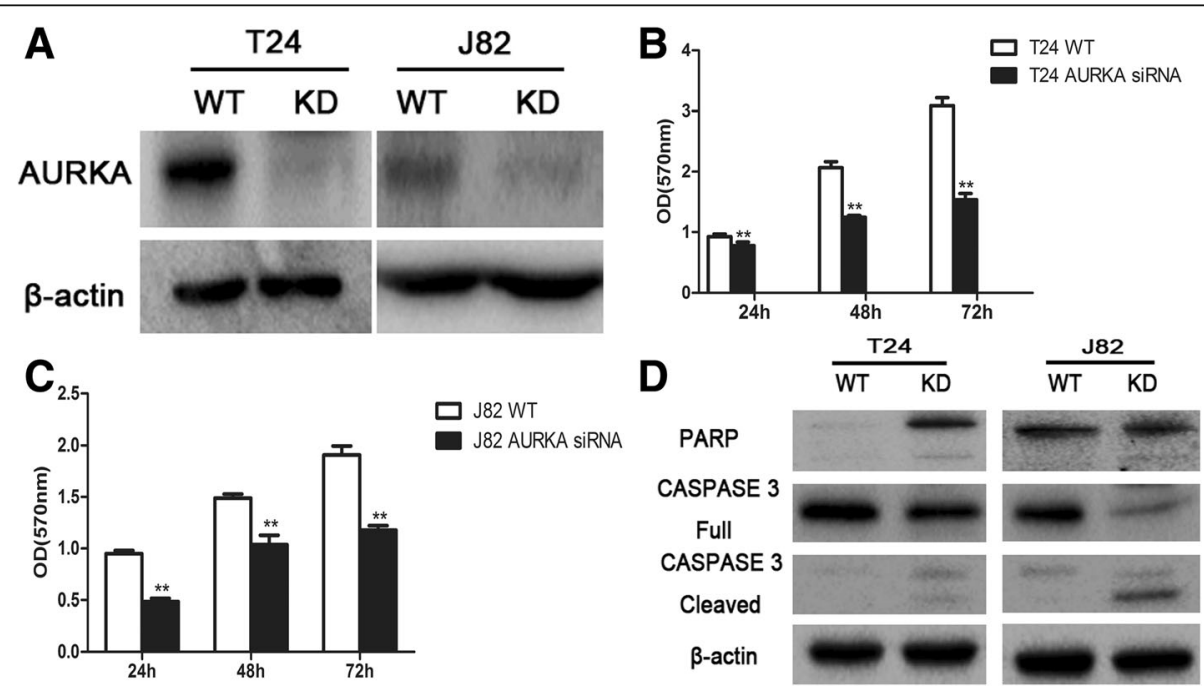

D

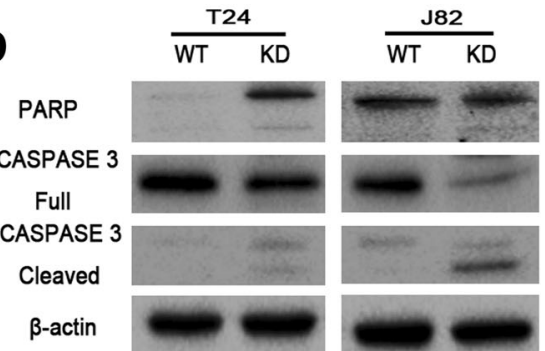

Fig. 3 Silencing AURKA expression inhibits the proliferation of BC cells. a AURKA expression in T24 and J82 cells were detected by western blot after AURKA-siRNA transfection. $\mathbf{b}$ and $\mathbf{c}$ Cell proliferation of $\mathbf{b}$ T24 and $\mathbf{c} J 82$ AURKA-knockdown (KD) and untransfected cells (WT). d Western blot of T24 and J82 Ctrl and KD cells on the PARP and Caspase 3 expression. ( $\left(P<0.05,{ }^{* *} P<0.01\right)$ 


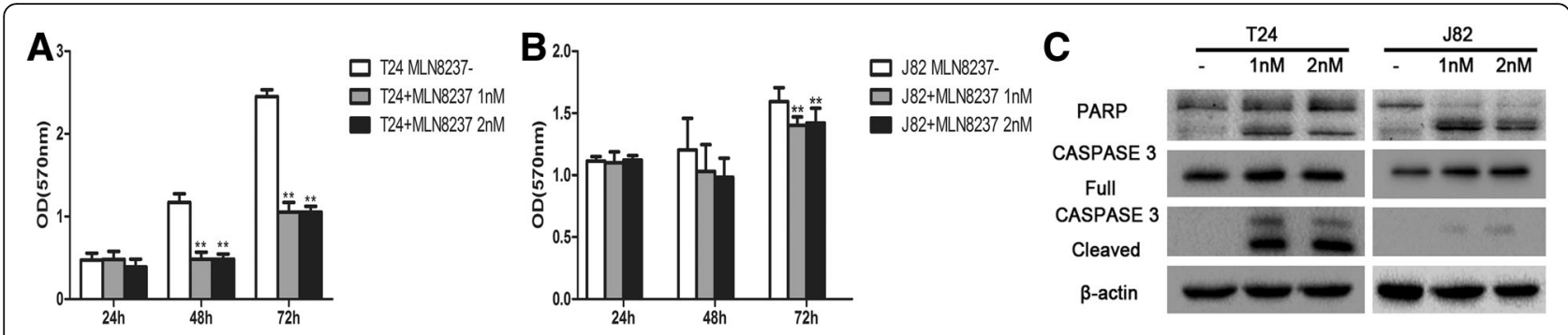

Fig. 4 MLN8237 treatment suppresses BC cell proliferation. $\mathbf{a}$ and $\mathbf{b}$ Cell proliferation of $\mathbf{a}$ T24 and $\mathbf{b} J 82$ cells after MLN8237 treatment. $\mathbf{c}$ PARP and Caspase 3 expression by Western blot in T24 and J82 cells after MLN8237 treatment $\left({ }^{*} P<0.05,{ }^{* *} P<0.01\right)$

found that the sensitivity, specificity and area under the ROC curve were 96.6, 87 and 93.9\%, respectively [15]. Our research combined gene expression omnibus data excavation, meta-analysis and in vitro experiments to obtain an exhaustive estimation of AURKA expression in the carcinogenesis and progression of BC.

Significant elevated AURKA was observed in PBC and RBC cells compared to NC and Surroundings by using publicly available GEP datasets. Stage and grade have been regarded as one of the most critical predictors of tumor recurrence and progression [25]. Our findings are consistent with the previous reports that higher expression of AURKA is associated with higher grades and stages [26, 27]. More importantly, patients with high AURKA expression suffered from worse survival than AURKA low-expressing patients. Anti-apoptosis was regarded as a distinct characteristic of tumor development [28]. Previous research has revealed the positive regulatory function of cleaved PARP and Caspase- 3 in the onset of apoptosis [29]. Activation of the apoptotic pathway following AURKA inhibition constitutes an important mechanism for achieving cell death [30]. Our data was supported by the other findings that transfection of miR-124-3p mimics and AURKA siRNA down-regulate $\mathrm{BC}$ cell proliferation and migration as well as induce cell apoptosis [9]. In addition, MLN8237 actives cleaved PARP and Caspase- 3 resulting in cell apoptosis, which is in accordance with the previous research performing on esophageal adenocarcinoma cells [31]. MLN8237 has been tested in various phase I and phase II clinical trials for advanced solid tumors and hematologic malignancies [32]. These data provide useful information for further therapeutic investigation of MLN8237 and other AURKA inhibitors in BC.

\section{Conclusions}

Collectively, our findings have disclosed the oncogenetic functions of AURKA in BC based on its prospective diagnostic and prognostic significance. Targeting AURKA may afford a novel treatment approach to bladder cancer.

\section{Methods}

\section{Cell lines and cell culture}

Human BC cell lines, T24 and J82, were maintained in DMEM and $\alpha$-MEM medium ((Hyclone Laboratory, Logan, UT), respectively, both of which were supplemented with $10 \%$ heat-inactivated fetal bovine serum (FBS) (Gibco, Grand Island, NY), 1\% penicillin and streptomycin (P/S) solution (Sigma, St. Louis, MO) at $37^{\circ} \mathrm{C}$ in a $5 \% \mathrm{CO}_{2}$ incubator.

\section{Reagents}

Antibodies of AURKA, Caspase-3 and cleaved PARP were purchased from Cell Signaling Technology (Danvers, MA). GAPDH antibody was obtained from SinoBiological (Beijing, China). AURKA inhibitor, MLN8237, was supplied by Aladdin (Shanghai, China), with the relative molecular weight of 518.94. MLN8237 stock solution $(8 \mu \mathrm{M})$ was prepared in DMSO and diluted into $1 \mathrm{nM}$ and $2 \mathrm{nM}$ with cell culture media.

\section{Cell transfection}

\section{Plasmid transfection}

The plasmid for overexpression of AURKA was constructed as previous described [33], named as pCMV2-FLAG-AURKA. Its reference sequence is NM_198433.1. The size is $1212 \mathrm{bp}$ in total, of which the position ranging from 567 to 1778 . T24 and J82 cells were incubated at $37{ }^{\circ} \mathrm{C}$ and $5 \% \mathrm{CO}_{2}$ overnight until the cells had reached $80 \% \sim 90 \%$ confluences. $1 \mu \mathrm{g}$ of pCMV2-FLAG-AURKA and $2 \mu \mathrm{L}$ of lip2000 were added to T24 and J82 cells with penicillin and streptomycin-free medium. Cells were incubated at $37{ }^{\circ} \mathrm{C}$ and $5 \% \mathrm{CO}_{2}$ for $6 \mathrm{~h}$, the medium was then replaced with complete medium. Transfected efficiency was verified by Western blot.

\section{RNA interference}

The AURKA-siRNA sequence was as following: AURKA-Homo-947 5' 3':GGGCUUUGGAAGACUUU GATTUCAAAGUCUUCCAAAGCCCTT. Sequences were chemically synthesized by GenePharma Co., Ltd. (Shanghai, China). For transfection experiments with siRNA directed against AURKA, the medium for T24 and 
J82 cells were changed to penicillin and streptomycin-free medium and confluence of cells were $30-50 \%$. Then, the cells were cotransfected with $2 \mu \mathrm{L}$ of siRNA and $1 \mu \mathrm{L}$ of lip2000. After $6 \mathrm{~h}$, the medium was changed to complete medium. Transfected efficiency was verified by Western blot.

\section{Cell growth assays}

Following transfection or MLN8237 treament, cell growth was evaluated using an MTT assay at $24 \mathrm{~h}, 48 \mathrm{~h}$ and $72 \mathrm{~h}$ after seeding. Cells were inoculated onto 96-well plates at the density of $4000 \sim 5000$ cells/well. After incubated for $2 \mathrm{~h}-4 \mathrm{~h}$, two concentrations of MLN8237 were added to the cells. After $48 \mathrm{~h}$ continuous exposure to the compounds at $37{ }^{\circ} \mathrm{C}$ and $5 \% \mathrm{CO}_{2}, 10 \mu \mathrm{L}$ of MTT and $90 \mu \mathrm{L}$ of complete medium were added to each well, incubating for $4 \mathrm{~h}$. The culture medium was removed and $150 \mu \mathrm{L}$ dimethyl sulfoxide was added to each well. After vigorous shaking for $10 \mathrm{~min}$, the absorbance (optical density, OD) of the reaction solution was measured at $570 \mathrm{~nm}$ by microplate reader.

\section{Western blot analysis}

Western blots were utilized to measure the protein levels of AURKA and apoptotic markers in BC cells. In brief, around $20 \mu \mathrm{g}$ protein per sample was extracted and analyzed by SDS-PAGE. Then the cell extract was transferred to a $0.45 \mu \mathrm{m}$ immobilon-P transfer membrane (Millipore, Bedford, MA). After incubated with primary and second antibodies, detection of specific proteins was carried out by ECL (Amersham Pharmacia Biotech, Piscataway, NJ).

\section{Gene expression profiling (GEP) and data analysis}

Gene expression data were publicly available from NIH Gene Expression Omnibus. The datasets of bladder cancer used in our study were GSE13507 $(n=256)$ and GSE31684 $(n=93)$. The GSE13507 dataset contains 10 normal bladder mucosae (NC), 58 normal looking bladder mucosae with surrounding carcinoma (Surrounding), 165 primary bladder cancer (PBC) samples and 23 recurrent bladder cancer (RBC) samples. The GSE31684 dataset contains 93 patients undergoing radical cystectomy (RC). GEP was conducted by Affymetrix U133 Plus 2.0 microarrays as previously described [34, 35].

\section{Statistical analysis}

All data were presented as means \pm SD. Two experimental groups were analyzed by Student's $t$ test, while multiple $(n \geq 3)$ groups were analyzed with one-way ANOVA. The patient survival data were sketched by the Kaplan-Meier method, and a log-rank test was performed to estimate survival curves. A Chi-square test was performed for clinicopathologic categorical variables to compare the high expression cohort with the low expression cohort. The significance level was set at $P<0.05$.

\section{Abbreviations}

AURKA: Aurora kinase A; BC: Bladder cancer; GEP: Gene expression profiling: MI: Muscle-invasive; PARP: Poly ADP-ribose polymerase; PBC: Primary bladder cancer; RBC: Recurrent bladder cancer; RC: Radical cystectomy

\section{Funding}

This work was supported by National Natural Science Foundation of China 81670200,81500166 (to YY). This research was also supported, in part, by the $\mathrm{NIH}$ grant 5P30GM114737, the NIH grant P20GM103466, the NIH Grant 2U54MD007601 and the NIH grant U54 MD007584.

\section{Availability of data and materials}

All data generated or analysed during this study are included in this published article.

\section{About this supplement}

This article has been published as part of BMC Systems Biology Volume 12 Supplement 7, 2018: From Genomics to Systems Biology. The full contents of the supplement are available online at https:/bmcsystbiol.biomedcentral.com/ articles/supplements/volume-12-supplement-7.

\section{Authors' contributions}

MJG, SCL, HMH conducted experiments and wrote the manuscript. ZMF, BJ and YPD designed the research, helped with interpretation of results, and wrote the manuscript. YHW, YPD and MQY provided guidance on data analysis. YY helped to interpret the results. All authors read and approved the final manuscript.

Ethics approval and consent to participate

Not applicable.

\section{Consent for publication}

Not applicable.

\section{Competing interests}

None of the authors above has disclosed a conflicts of interest with this submission.

\section{Publisher's Note}

Springer Nature remains neutral with regard to jurisdictional claims in published maps and institutional affiliations.

\section{Author details}

${ }^{1}$ School of Medicine and Life Sciences, Nanjing University of Chinese Medicine, Nanjing 210023, China. ${ }^{2}$ Department of Hematology, Affiliated Hospital of Nantong University, Nantong 226001, China. ${ }^{3}$ Department of Pathology, Jiangsu Province Hospital of Traditional Chinese Medicine, Nanjing 210029, China. ${ }^{4}$ MidSouth Bioinformatics Center, Department of Information Science, George Washington Donaghey College of Engineering and Information Technology and Joint Bioinformatics Graduate Program, University of Arkansas at Little Rock and University of Arkansas for Medical Sciences, Little Rock, AR 72204, USA. ${ }^{5}$ National Medical Centre of Colorectal Disease, The Third Affiliated Hospital of Nanjing University of Chinese Medicine, Nanjing 210001, China. ${ }^{6}$ Integrated Medical College, Nanjing

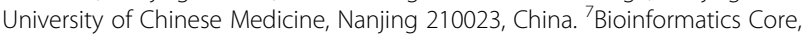
Department of Complementary \& Integrative Medicine, University of Hawaii John A. Burns School of Medicine, Honolulu, HI 96813, USA.

Published: 14 December 2018

References

1. Moreira JM, Ohlsson G, Gromov P, Simon R, Sauter G, Celis JE, Gromova I. Bladder cancer-associated protein, a potential prognostic biomarker in human bladder cancer. Mol Cell Proteomics. 2010;9:161-77.

2. Gong Y, Qiu W, Ning X, Yang X, Liu L, Wang Z, Lin J, Li X, Guo Y. CCDC34 is up-regulated in bladder cancer and regulates bladder cancer cell proliferation, apoptosis and migration. Oncotarget. 2015;6:25856-67.

3. Zhang T, Wu K, Ding C, Sun K, Guan Z, Wang X, Hsieh JT, He D, Fan J. Inhibiting bladder tumor growth with a cell penetrating R11 peptide derived from the p53 C-terminus. Oncotarget. 2015;6:37782-91. 
4. Breau RH, Karnes RJ, Farmer SA, Thapa P, Cagiannos I, Morash C, Frank I. Progression to detrusor muscle invasion during urothelial carcinoma surveillance is associated with poor prognosis. BJU Int. 2014;113:900-6.

5. Zhou N, Singh K, Mir MC, Parker Y, Lindner D, Dreicer R, Ecsedy JA, Zhang Z, Teh BT, Almasan A, Hansel DE. The investigational Aurora kinase a inhibitor MLN8237 induces defects in cell viability and cell-cycle progression in malignant bladder cancer cells in vitro and in vivo. Clin Cancer Res. 2013;19: 1717-28.

6. Riester M, Taylor JM, Feifer A, Koppie T, Rosenberg JE, Downey RJ, Bochner $\mathrm{BH}$, Michor $\mathrm{F}$. Combination of a novel gene expression signature with a clinical nomogram improves the prediction of survival in high-risk bladder cancer. Clin Cancer Res. 2012;18:1323-33.

7. Kim WJ, Kim EJ, Kim SK, Kim YJ, Ha YS, Jeong P, Kim MJ, Yun SJ, Lee KM, Moon SK, Lee SC, Cha EJ, Bae SC. Predictive value of progression-related gene classifier in primary non-muscle invasive bladder cancer. Mol Cancer. 2010;9:3.

8. Goos JA, Coupe VM, Diosdado B, Delis-Van Diemen PM, Karga C, Belien JA Carvalho B, van den Tol MP, Verheul HM, Geldof AA, Meijer GA, Hoekstra OS, Fijneman RJ. Aurora kinase a (AURKA) expression in colorectal cancer liver metastasis is associated with poor prognosis. Br J Cancer. 2013;109: 2445-52.

9. Yuan $Q$, Sun T, Ye F, Kong W, Jin H. MicroRNA-124-3p affects proliferation, migration and apoptosis of bladder cancer cells through targeting AURKA. Cancer Biomark. 2017;19:93-101.

10. Mathison A, Salmonson A, Missfeldt M, Bintz J, Williams M, Kossak S, Nair A, de Assuncao TM, Christensen T, Buttar N, lovanna J, Huebert R, Lomberk G. Combined AURKA and H3K9 methyltransferase targeting inhibits cell growth by inducing mitotic catastrophe. Mol Cancer Res. 2017;15:984-97.

11. Fanale D, Bazan V, Corsini LR, Caruso S, Insalaco L, Castiglia M, Cicero G, Bronte G, Russo A. HIF-1 is involved in the negative regulation of AURKA expression in breast cancer cell lines under hypoxic conditions. Breast Cancer Res Treat. 2013;140:505-17.

12. Yang J, Ikezoe T, Nishioka C, Udaka K, Yokoyama A. Bcr-Abl activates AURKA and AURKB in chronic myeloid leukemia cells via AKT signaling. Int J Cancer. 2014;134:1183-94.

13. Chen C, Song G, Xiang J, Zhang H, Zhao S, Zhan Y. AURKA promotes cancer metastasis by regulating epithelial-mesenchymal transition and cancer stem cell properties in hepatocellular carcinoma. Biochem Biophys Res Commun. 2017;486:514-20.

14. Zhu J, Abbruzzese JL, Izzo J, Hittelman WN, Li D. AURKA amplification, chromosome instability, and centrosome abnormality in human pancreatic carcinoma cells. Cancer Genet Cytogenet. 2005;159:10-7.

15. Park HS, Park WS, Bondaruk J, Tanaka N, Katayama H, Lee S, Spiess PE, Steinberg JR, Wang Z, Katz RL, Dinney C, Elias KJ, Lotan Y, et al. Quantitation of Aurora kinase a gene copy number in urine sediments and bladder cancer detection. J Natl Cancer Inst. 2008;100:1401-11.

16. Feng $Y$, Liu J, Kang $Y$, He Y, Liang B, Yang $P$, Yu Z. miR-19a acts as an oncogenic microRNA and is up-regulated in bladder cancer. J Exp Clin Cancer Res. 2014;33:67.

17. Knowles MA. Molecular pathogenesis of bladder cancer. Int J Clin Oncol. 2008;13:287-97.

18. Deloukas P, Matthews LH, Ashurst J, Burton J, Gilbert JG, Jones M, Stavrides G, Almeida JP, Babbage AK, Bagguley CL, Bailey J, Barlow KF, Bates KN, et al. The DNA sequence and comparative analysis of human chromosome 20. Nature. 2001;414:865-71.

19. Sillars-Hardebol AH, Carvalho B, Tijssen M, Belien JA, de Wit M, Delis-van Diemen PM, Ponten F, van de Wiel MA, Fijneman RJ, Meijer GA. TPX2 and AURKA promote $20 \mathrm{q}$ amplicon-driven colorectal adenoma to carcinoma progression. Gut. 2012;61:1568-75.

20. Savelieva E, Belair CD, Newton MA, DeVries S, Gray JW, Waldman F, Reznikoff CA. 20q gain associates with immortalization: 20q13.2 amplification correlates with genome instability in human papillomavirus 16 E7 transformed human uroepithelial cells. Oncogene. 1997;14:551-60.

21. Dai ZJ, Kang HF, Wang XJ, Shao YP, Lin S, Zhao Y, Ren HT, Min WL, Wang M, Liu XX. Association between genetic polymorphisms in AURKA (rs2273535 and rs1047972) and breast cancer risk: a meta-analysis involving 37,221 subjects. Cancer Cell Int. 2014;14:91.

22. Liu X, Li Z, Song Y, Wang R, Han L, Wang Q, Jiang K, Kang C, Zhang Q. AURKA induces EMT by regulating histone modification through Wnt/betacatenin and PI3K/Akt signaling pathway in gastric cancer. Oncotarget. 2016; 7:33152-64.
23. Chuang TP, Wang JY, Jao SW, Wu CC, Chen JH, Hsiao KH, Lin CY, Chen SH, Su SY, Chen YJ, Chen YT, Wu DC, Li LH. Over-expression of AURKA, SKA3 and DSN1 contributes to colorectal adenoma to carcinoma progression. Oncotarget. 2016;7:45803-18.

24. de Martino M, Shariat SF, Hofbauer SL, Lucca I, Taus C, Wiener HG, Haitel A, Susani M, Klatte T. Aurora a kinase as a diagnostic urinary marker for urothelial bladder cancer. World J Urol. 2015;33:105-10.

25. Faba OR, Palou J, Breda A, Villavicencio H. High-risk non-muscle-invasive bladder cancer: update for a better identification and treatment. World J Urol. 2012;30:833-40.

26. Bufo P, Sanguedolce F, Tortorella S, Cormio L, Carrieri G, Pannone G. Expression of mitotic kinases phospho-aurora a and aurora B correlates with clinical and pathological parameters in bladder neoplasms. Histol Histopathol. 2010;25:1371-7.

27. Comperat E, Bieche I, Dargere D, Laurendeau I, Vieillefond A, Benoit G, Vidaud M, Camparo P, Capron F, Verret C, Cussenot O, Bedossa P, Paradis V. Gene expression study of Aurora-a reveals implication during bladder carcinogenesis and increasing values in invasive urothelial cancer. Urology. 2008;72:873-7.

28. Brown JM, Attardi LD. The role of apoptosis in cancer development and treatment response. Nat Rev Cancer. 2005;5:231-7.

29. Boulares AH, Yakovlev AG, Ivanova V, Stoica BA, Wang G, Iyer S, Smulson M. Role of poly (ADP-ribose) polymerase (PARP) cleavage in apoptosis. Caspase 3-resistant PARP mutant increases rates of apoptosis in transfected cells. J Biol Chem. 1999;274:22932-40.

30. Sehdev V, Katsha A, Ecsedy J, Zaika A, Belkhiri A, El-Rifai W. The combination of alisertib, an investigational Aurora kinase a inhibitor, and docetaxel promotes cell death and reduces tumor growth in preclinical cell models of upper gastrointestinal adenocarcinomas. Cancer. 2013;119:904-14.

31. Sehdev V, Peng D, Soutto M, Washington MK, Revetta F, Ecsedy J, Zaika A, Rau T, Schneider-Stock R, Belkhiri A, El-Rifai W. The aurora kinase a inhibitor MLN8237 enhances cisplatin-induced cell death in esophageal adenocarcinoma cells. Mol Cancer Ther. 2012:11:763-74.

32. Gorgun G, Calabrese E, Hideshima T, Ecsedy J, Perrone G, Mani M, Ikeda H, Bianchi G, Hu Y, Cirstea D, Santo L, Tai YT, Nahar S, et al. A novel Aurora-a kinase inhibitor MLN8237 induces cytotoxicity and cell-cycle arrest in multiple myeloma. Blood. 2010;115:5202-13.

33. Chen J, Lu H, Zhou W, Yin H, Zhu L, Liu C, Zhang P, Hu H, Yang Y, Han H. AURKA upregulation plays a role in fibroblast-reduced gefitinib sensitivity in the NSCLC cell line HCC827. Oncol Rep. 2015;33:1860-6.

34. Gu $C$, Feng $L$, Peng $H$, Yang $H$, Feng $Z$, Yang $Y$. MTDH is an oncogene in multiple myeloma, which is suppressed by Bortezomib treatment. Oncotarget. 2016;7:4559-69.

35. Tsai MC, Li WM, Huang CN, Ke HL, Li CC, Yeh HC, Chan TC, Liang PI, Yeh BW, Wu WJ, Lim SW, Li CF. DDR2 overexpression in urothelial carcinoma indicates an unfavorable prognosis: a large cohort study. Oncotarget. 2016; 7:78918-31

\section{Ready to submit your research? Choose BMC and benefit from:}

- fast, convenient online submission

- thorough peer review by experienced researchers in your field

- rapid publication on acceptance

- support for research data, including large and complex data types

- gold Open Access which fosters wider collaboration and increased citations

- maximum visibility for your research: over $100 \mathrm{M}$ website views per year

At BMC, research is always in progress.

Learn more biomedcentral.com/submission 